\title{
Analisis Nilai Tambah Ayam Pedaging Menjadi Bakso Ayam Di Kecamatan Belitang Kabupaten Oku Timur
}

\author{
Parmaji \\ Sekolah Tinggi Ilmu Pertanian Belitang \\ Jln.Kampus Pertanian No.3 Belitang Kabupaten OKU Timur Provinsi Sumatera Selatan \\ e-mail: parmajiaji@gmail.com
}

\begin{abstract}
The objectives of this study were to: 1) determine the added value of broilers into meatballs in Belitang District, East OKU Regency, 2) to determine the financial feasibility of making chicken meatballs in Belitang District, East OKU Regency. The results showed that the total production cost for the business of making chicken meatballs in Belitang District, East OKU Regency in one production process on average is Rp. 358,520, revenue is $R p .440,000$, and the income received is Rp. 81,480. The amount of added value in the business of making chicken meatballs in Belitang District, East OKU Regency in one process is IDR 162,813 or 45,562 / Kg. This shows that each making chicken meatball from $1 \mathrm{~kg}$ of chicken will provide an added value of Rp. 44,284. The business of making chicken meatballs in Belitang District, East OKU Regency is financially feasible, this can be seen from the calculation of the NPV value of IDR 27,692,459, the IRR value is $64.99 \%$ and the Net B / C value is 1.98. .
\end{abstract}

Key Words : Value-added, Broilers, Agro industry.

\section{PENDAHULUAN}

\section{A. Latar Belakang}

Peternakan merupakan salah satu cabang dari sektor pertanian. Di Indonesia banyak terdapat industri pengolahan hasil peternakan, salah satunya adalah industri pengolahan daging. Daging merupakan bahan pangan yang penting dalam memenuhi kebutuhan gizi. Selain mutu proteinnya tinggi, pada daging terdapat pula kandungan asam amino esensial yang lengkap dan seimbang. Keunggulan lain, protein daging lebih mudah dicerna daripada yang berasal dari nabati. Bahan pangan ini juga mengandung beberapa jenis mineral dan vitamin.

Usaha pengolahan daging ayam menjadi bakso merupakan pemanfaatan produk pertanian yang mengolah hasil daging dari peternakan menjadi produk bakso ayam yang bernilai lebih tinggi serta meningkat pula kemanfaatannya. Bakso ayam adalah campuran homogen daging, tepung pati dan bumbu yang telah mengalami proses ekstrusi dan pemasakan.

Tingkat konsumsi daging tertinggi adalah daging ayam broiler sebesar $12,5 \mathrm{~kg} / \mathrm{kapita} / \mathrm{tahun}$, sedangkan tingkat konsumsi daging ayam hanya sebesar 20,8 $\mathrm{kg} / \mathrm{kapita} /$ tahun. Tingginya tingkat konsumsi daging ayam broiler juga didukung oleh banyaknya jumlah penduduk (Departemen Pertanian, 2018). Provinsi Sumatera Selatan sebagai pusat pemerintahan memiliki kepadatan penduduk yang tinggi. Berdasarkan survei sosial ekonomi nasional tahun 2018, jumlah penduduk di Sumatera Selatan mencapai 8.391.875 jiwa dengan 47,24 \% penduduknya memiliki rata-rata pengeluaran lebih dari lima ratus ribu rupiah per kapita per bulan.
Kabupaten OKU Timur merupakan sebuah kabupaten yang terletak di Provinsi Sumatera Selatan. Kabupaten OKU Timur merupakan kabupaten yang sangat berkembang di Provinsi Sumatra Selatan khususnya di bidang pertanian dan peternakan. Kabupaten OKU Timur sangat identik dengan pertanian dan peternakannya khususnya peternakan ayam. Banyaknya permintaan konsumen terhadap daging ayam sehingga usaha ini melakukan banyak cara supaya untuk memunculkan sebuah inovasi yang bisa meningkatkan pendapatan bagi penduduk di Kabupaten OKU Timur khususnya subsektor peternakan.

Agroindustri merupakan suatu bentuk kegiatan atau aktifitas yang mengolah bahan baku yang berasal dari tanaman maupun hewan. Soekartawi, (2003), mendefinisikan agroindustri dalam dua hal, yaitu pertama agroindustri sebagai industri yang berbahan baku utama dari produk pertanian dan kedua agroindustri sebagai suatu tahapan pembangunan sebagai kelanjutan dari pembangunan pertanian tetapi sebelum tahapan pembangunan tersebut mencapai tahapan pembangunan industri. Agroindustri memiliki peranan yang sangat penting dalam pembangunan pertanian. Hal ini dapat dilihat dari kontribusinya dalam hal meningkatkan pendapatan pelaku agribisnis, menyerap tenaga kerja, meningkatkan perolehan devisa dan mendorong tumbuhnya industri lain. Salah satu bentuk kegiatan agroindustri adalah pengolahan daging ayam broiler menjadi bakso ayam.

Penduduk Kabupaten OKU Timur saat ini telah mengikuti gaya hidup modern khusunya dalam bidang pangan. Masyarakatnya telah banyak yang mengkonsumsi pangan siap saji hal inilah yang membuka peluang bagi pengusaha untuk membuka industry pangan olahan seperti bakso ayam salah 
satunya. Masyarakat OKU Timur juga banyak yang meminati makanan bakso ayam ini. Dengan adanya dukungan peternakan ayam yang banyak diusahakan di kabupaten ini, membuka peluang bagi industri pangan olahan untuk berusaha dalam bidang pangan olahan.

Kecamatan Belitang merupakan kecamatan yang terletak di Kabupaten OKU Timur. Kecamatan Belitang merupakan kecamatan yang berkembang di Kabupaten OKU Timur baik dari segi pendidikan, ekonomi, pertanian. Hal ini dilihat dari penduduknya yang mempunyai gaya hidup yang cukup maju. Penduduk Kecamatan Belitang mayoritas mempunyai pekerjaan petani, peternak sapi dan pedagang. Di kecamatan ini juga terdapat usaha yang bergerak di bidang penggilingan daging bakso ayam dan pembuatan bakso ayam yang dimana usaha ini cukup besar dan berkembang di Kecamatan Belitang.

Banyaknya permintaan konsumen terhadap daging ayam khususnya di Kecamatan Belitang sehingga pengusaha melakukan banyak cara supaya bisa mencukupi permintaan pasar, salah satunya adalah ide kreatif yang bisa menghasilkan nilai tambah bagi usaha pengelolah daging ayam serta meningkatkan pendapatan dan membantu menyokong pertanian di Kecamatan Belitang khususnya subsektor peternakan.

\section{B. Rumusan Masalah}

Adapun rumusan dalam penelitian adalah :

1. Berapa besar nilai tambah pengolahan ayam pedaging menjadi bakso di Kecamatan Belitang Kabupaten OKU Timur?

2. Bagaimana kelayakan finansial pembuatan bakso ayam di Kecamatan Belitang Kabupaten OKU Timur?

\section{Tujuan dan Kegunaan Penelitian}

Adapun tujuan dari penelitian ini adalah:

1. Untuk mengetahui nilai tambah ayam pedaging menjadi bakso di Kecamatan Belitang Kabupaten OKU Timur.

2. Untuk mengetahui kelayakan finansial pembuatan bakso ayam di Kecamatan Belitang Kabupaten OKU Timur.

Sedangkan kegunaan dari penelitian ini adalah penelitian dapat berguna bagi pihak-pihak yang berkepentingan yaitu :

1. Sebagai informasi atau referensi dalam mengembangkan ilmu pengetahuan bagi penulis.

2. Sebagai bahan informasi dan referensi bagi peneliti selanjutnya yang terkait dengan penelitian ini.

3. Sebagai bahan informasi dan referensi bagi khalayak pada umumnya dan bagi peternak serta pengolah hasil pangan pada umumnya.

\section{Hipotesis}

Berdasarkan uraian yang telah digunakan dalam latar belakang, permasalahan, tujuan dan tinjauan pustaka, maka hipotesis yang diajukan dalam penelitian ini adalah :

1. Bahwa pembuatan daging ayam menjadi bakso di Kecamatan Belitang Kabupaten OKU Timur memperoleh nilai tambah.

2. Bahwa pembuatan bakso ayam di Kecamatan Belitang Kabupaten OKU Timur layak secara finansial.

\section{KERANGKA TEORITIS}

\section{A. Tinjauan Pustaka}

\section{B. Model Pendekatan}

Penelitian ini telah dilaksanakan dengan menggunakan model pendekatan secara diagramatis yang digambarkan sebagai berikut:

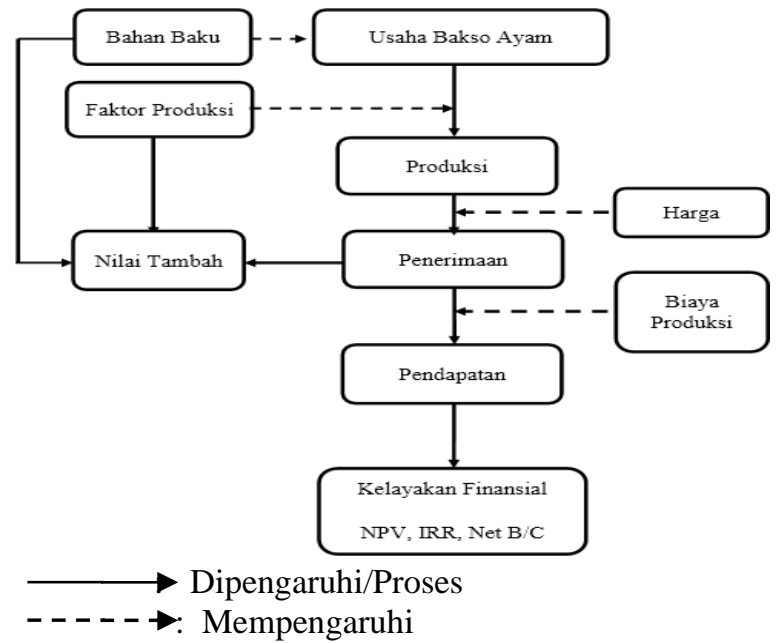

Gambar 1. Model Pendekatan Secara Diagramatis

C. Pembatasan Masalah

1. Responden adalah pelaku pengolahan daging ayam menjadi bakso di Kecamatan Belitang Kabupaten OKU Timur.

2. Bahan baku yang digunakan adalah potongan daging ayam broiler yang langsung dibeli di pasar $(\mathrm{Rp} / \mathrm{Kg})$.

3. Penjual adalah penjual bakso ayam yang ada di Kecamatan Belitang Kabupaten OKU Timur yang dipasarkan di Pasar Gumawang OKU Timur dalam bentuk buletan bakso.

4. Biaya tetap adalah biaya yang penggunaanya tidak habis dalam satu kali proses produksi pembuatan bakso ayam dan biaya yang besar kecilnya tidak mempengaruhi oleh jumlah produksi bakso ayam (Rp/PP).

5. Biaya variabel adalah biaya yang jumlahnya tergantung dari besarnya jumlah produksi bakso ayam serta habis dalam satu kali proses produksi pembuatan bulatan bakso ayam (Rp/PP).

6. Biaya produksi adalah total biaya yang dikeluarkan dalam satu kali proses produksi dalam pembuatan bulatan bakso ayam yang meliputi biaya tetap dan biaya variabel $(\mathrm{Rp} / \mathrm{PP})$. 
7. Produksi adalah produk yang dihasilkan oleh responden berupa bakso ayam dalam bentuk bulatan bakso $(\mathrm{Kg})$.

8. Harga adalah nilai jual dari bakso ayam yang ditetapkan oleh responden pada saat penelitian (Rp/Kg).

9. Penerimaan adalah jumlah dari hasil produksi $(\mathrm{Kg})$ yang diperoleh home industri pembuatan bakso ayam dikali dengan harga buletan bakso ayam $(\mathrm{Rp} / \mathrm{Kg})$ pada saat penelitian $(\mathrm{Rp} / \mathrm{PP})$.

10. Pendapatan adalah selisih antara penerimaan bakso ayam dengan biaya produksi yang dikeluarkan selama proses produksi pembuatan bakso ayam berlangsung (Rp/PP).

11. Pasar adalah tempat bertemunya penjual dan pembeli serta ditandai dengan adanya transaksi penjual pembeli secara langsung dan biasanya ada proses tawar menawar.

12. Pengecer adalah organisasi ataupun seseorang yang menjalankan penjualan bakso ayam secara langsung ke konsumen akhir untuk penggunaan pribadi dan bukan bisnis.

13. Nilai tambah adalah selisih antara nilai output yang dihasilkan dengan biaya antara bahan baku dari pembuatan bakso ayam $(\mathrm{Rp} / \mathrm{Kg})$.

14. Kelayakan usaha adalah analisis terhadap usaha pembuatan bakso ayam secara ekonomis menguntungkan dan layak secara finansial yang dilihat melalui perhitungan NPV, IRR dan Net B/C.

15. NPV (Net Present Value) adalah perhitungan untuk mengetahui hasil keuntungan bersih yang diterima pada tahun mendatang dengan jumlah nilai sekarang dan memperhitungkan tingkat bunga selama tahun berjalan.

16. IRR (Internal of Retrun) digunakan untuk meyakinkan dan mengetahui atau mengevaluasi tingkat investasi atau penghasilan lebih dari usaha yang akan dilaksanakan menurut suku bunga yang berlaku.

17. Net B/C (Net Benefit Cost) adalah perbandingan antara net benefit yang telah discount positif (+) dengan net benefit yang telah di discount negative (-). Apabila suatu usaha atau investasi dikatakan layak secara finansial apabila memiliki nilai Net B/C Ratio $>1$.

\section{METODE PENELITIAN}

\section{A. Tempat dan Waktu}

Penalitian ini telah dilaksanakan di Kecamatan Belitang Kabupaten OKU Timur Provinsi Sumatera Selatan. Penentuan lokasi ini dilakukan secara sengaja (purposive) karena di kecamatan tersebut terdapat usaha pembuatan bakso ayam yang tersebar di beberapa desa dan dipasarkan secara langsung di Pasar Gumawang. Penelitian ini dilaksanakan pada Bulan Juni - Juli 2019.

\section{B. Metode Penelitian dan Penarikan Contoh}

Metode penelitian yang digunakan dalam penelitin ini adalah metode survey. Pengertian survey dibatasi pada pengertian survey sampel dimana informasi dikumpulkan dari beberapa populasi untuk mewakili seluruh populasi (Margono, 2005). Dalam penelitian survei bahwa informasi dikumpulkan dari responden dengan menggunakan quisioner sebagai alat pengumpul data yang pokok.

Sedangkan metode penarikan contoh yang digunakan pada saat penelitian adalah metode sensus. Metode sensus adalah suatu metode penentuan sample bila semua anggota populasi dijadikan sebagai sample (Nazir, 2010). Dalam penelitian ini sample berjumlah tiga responden yang melakukan usaha pengolahan daging ayam menjadi bakso ayam di Kecamatan Belitang Kabupaten OKU Timur. Secara rinci dapat dilihat pada tabel di bawah ini:

Tabel 1. Sampel Pembuatan Bakso Ayam di Kecamatan Belitang Kabupaten OKU Timur.

\begin{tabular}{clccc}
\hline No & \multicolumn{1}{c}{ Nama } & Desa & $\begin{array}{c}\text { Jumlah } \\
\text { Populasi }\end{array}$ & $\begin{array}{c}\text { Jumlah } \\
\text { Sampel }\end{array}$ \\
\hline 1. & Adi Lasmono & Pujorahayu & 1 & 1 \\
2. & Agus Miftah & Pujorahayu & 1 & 1 \\
3. & Rahman & Tegalrejo & 1 & 1 \\
\hline
\end{tabular}

Sumber : Olahan Data Primer, 2019.

\section{Metode Pengumpulan Data}

Metode pengumpulan data dilakukan yaitu dengan cara observasi langsung yang dilakukan dengan cara pengambilan data primer dan data sekunder :

1. Pengambilan data primer adalah data yang diperoleh dengan melakukan pengamatan secara langsung ke lokasi penelitian serta wawancara langsung menggunakan daftar pertanyaan (kuesioner) kepada pelaku usaha pengolahan daging ayam menjadi bakso ayam di Kecamatan Belitang Kabupaten OKU Timur.

2. Pengambilan data sekunder diperoleh dari data yang ada di kantor kecamatan yang terkait akan keadaan umum wilayah penelitian, dan data yang berasal dari buku-buku di perpustakaan dan jurnal.

\section{Metode Pengolahan Data}

Data yang diperoleh dari lapangan dianalisa mengunakan analisis matematis. Untuk menjawab hipotesis yang pertama, menggunakan beberapa rumus sebagai berikut:

1. Untuk menghitung biaya produksi (Soekartawi, 2002), dengan rumus :

$\mathrm{TC}=\mathrm{FC}+\mathrm{VC}$

Keterangan :

$\mathrm{TC}=$ Total Cost $/$ Biaya Produksi (Rp)

$\mathrm{FC}=$ Fixed Cost/ Biaya Tetap (Rp)

$\mathrm{VC}=$ Variable Cost/ Biaya Tidak Tetap $(\mathrm{Rp})$

2. Untuk menghitung penerimaan (Soekartawi, 2002), digunakan rumus :

$\mathrm{TR}=\mathrm{Y} \times \mathrm{Py}$.

Keterangan :

$\mathrm{TR}=$ Total Revenue/ Total Penerimaan $(\mathrm{Rp})$

$\mathrm{Y}=$ Output Produksi/ Hasil Produksi $(\mathrm{Kg})$ 
$\mathrm{P}=\operatorname{Harga}(\mathrm{Rp} / \mathrm{Kg})$

3. Untuk menghitung pendapatan (Soekartawi, 2002), digunakan rumus :

$\mathrm{I}=\mathrm{TR}-\mathrm{TC}$

Keterangan :

$\mathrm{I}=$ Income/ Pendapatan ( Rp)

$\mathrm{TR}=$ Total Revenue/ Penerimaan $(\mathrm{Rp})$

$\mathrm{TC}=$ Total Cost $/$ Total Biaya Produksi (Rp)

4. Untuk menghitung nilai tambah menggunakan rumus (Yudi, 2010):

$\mathrm{AV}=\mathrm{TR}-\mathrm{IC}$.

Keterangan :

$\mathrm{AV}=$ Added Value/ Nilai Tambah

$\mathrm{TR}=$ Total Revenue/ TotalPenerimaan

IC = Intermediate Cost/ Biaya Antara ( kecuali tenaga kerja keluarga)

Untuk menjawab hipotesis yang kedua, dapat menggunakan rumus sebagai berikut :

1. Net Present Value ( NPV) nilai kini bersih (Ibrahim, 2009)

$\mathrm{NPV}=\sum_{i=1}^{n} \mathrm{NB} i(1+i)^{-\mathrm{n}}$

Keterangan :

$\mathrm{NPV}=$ Net Present Value

$\mathrm{NB}=$ Net Benefit $=$ Benefit - Cost

$\mathrm{i}=$ Discount factor (tingkat suku bunga bank)

$\mathrm{n}=$ Tahun (waktu)

2. Internal Rate of Return (IRR) laju keberhasilan usaha (Ibrahim, 2009)

$\operatorname{IRR}=i_{1}+\frac{\mathrm{NPV} 1}{(N P V 1-N P V 2)} X\left(i_{2}-i_{1}\right)$

Keterangan:

$\mathrm{NPV}_{1}=\mathrm{NPV}$ pada tingkat discount rate terendah (positif)

$\mathrm{NPV}_{2}=\mathrm{NPV}$ pada tingkat discount rate tertinggi (negatif)

$i_{1}=$ Tingkat discount rate yang menghasilkan NPV1

$i_{2}=$ Tingkat discount rate yang menghasilkan NPV2

3. Net B/C Ratio (Ibrahim, 2009)

Net $\mathrm{B} / \mathrm{C}=\frac{\sum_{i=1}^{n} N \bar{B} i(+)}{\sum_{i=1}^{n} N \bar{B} i(-)}$

Dimana:

Net B/C > 1 berarti usaha tersebut layak secara finansial (feasible)

Net $\mathrm{B} / \mathrm{C}=1$ berarti usaha tidak untung tidak rugi (impas/BEP)

Net $\mathrm{B} / \mathrm{C}<1$ berarti usaha tidak menguntungkan (Non Feasible)

\section{HASIL DAN PEMBAHASAN}

\section{A. Analisis Usaha Pembuatan Bakso Ayam}

Analisis usaha digunakan sebagai tolak ukur suatu usaha apakah menguntungkan atau tidak dan apakah usaha tersebut layak untuk dikembangkan atau tidak. Untuk menganalisis usaha dalam penelitian ini adalah dengan menghitung berapa besar biaya produksi yang dikeluarkan, berapa jumlah produksi bakso ayam, berapa besar penerimaan dan pendapatan yang diperoleh oleh responden dan dengan analisis $\mathrm{R} / \mathrm{C}$ rasio.
Biaya produksi adalah semua nilai pengorbanan yang dikeluarkan dari berbagai faktor produksi dalam bentuk barang atau jasa yang digunakan selama proses produksi berlangsung. Biaya dalam usaha agribisnis meliputi biaya tetap dan biaya variabel. Biaya tetap adalah biaya yang tidak dipengaruhi oleh besar kecilnya produksi dan tidak habis dalam satu kali proses produksi yang meliputi biaya penyusutan alat dan biaya sewa lahan. Biaya variabel adalah biaya yang dipengaruhi oleh besar kecilnya produksi yang dihasilkan dan habis dalam satu kali proses produksi yang meliputi biaya sarana produksi dan biaya tenaga kerja.

Besarnya biaya produksi yang dikeluarkan akan berpengaruh terhadap pendapatan yang dihasilkan sehingga dalam melakukan usaha agribisnis harus lebih efisien dengan tujuan untuk menghasilkan keuntungan maksimum atau dengan menekan biaya produksi sekecil-kecilnya untuk mendapatkan keuntungan yang lebih besar. Berikut ini merupakan komponen biaya yang dikeluarkan dalam usaha pembuatan bakso ayam di Kecamatan Belitang Kabupaten OKU Timur :

\section{Biaya Tetap (Fixed Cost)}

Biaya tetap yang digunakan dalam usaha pembuatan Bakso Ayam di antaranya meliputi biaya sewa lahan dan biaya penyusutan peralatan. Adapun peralatan yang digunakan dalam usaha pembuatan bakso ikan antara lain adalah: motor, panic, kompor gas, sutil, timbangan, solet, baskom, ember, irik, tampah, sendok pengaduk, keruntung dan gayung. Adapun besarnya biaya tetap usaha pembuatan bakso ayam di Kecamatan Belitang Kabupaten OKU Timur dapat dilihat pada tabel 2 berikut :

Tabel 2. Biaya Tetap Usaha Pembuatan Bakso Ayam di Kecamatan Belitang Kabupaten OKU Timur, 2019.

\begin{tabular}{clr}
\hline No & Komponen Biaya & Nilai (Rp/Proses) \\
\hline 1. & Sewa Tempat Usaha & $\mathbf{6 . 0 1 9}$ \\
2. & Penyusutan Alat & $\mathbf{4 . 6 6 9}$ \\
& a. Motor & 2.756 \\
b. Panci & 215 \\
c. Kompor Gas & 355 \\
d. Sutil & 120 \\
e. Timbangan & 233 \\
f. Solet & 83 \\
g. Baskom & 144 \\
h. Ember & 93 \\
i. Irik & 139 \\
j. Tampah & 157 \\
k. Sendok & 167 \\
l. Keruntung & 139 \\
m. Gayung & 69 \\
\hline
\end{tabular}

3. Biaya Tetap

10.687

Sumber : Olahan Data Primer, 2019. 
Berdasarkan hasil analisis data di atas diketahui bahwa biaya sewa tempat usaha pembuatan bakso ayam di Kecamatan Belitang dalam satu kali proses produksi (1 hari) rata-rata adalah sebesar Rp 6.019 atau rata-rata sebesar Rp 180.556/Bulan. Adapun rata-rata biaya penyusutan peralatan usaha pembuatan bakso ayam dalam satu kali proses produksi adalah sebesar Rp 4.669 atau rata-rata sebesar Rp 140.058/Bulan. Adapun besarnya biaya tetap usaha pembuatan bakso ayam di Kecamatan Belitang Kabupaten OKU Timur yang terdiri dari biaya sewa lahan dan biaya penyusutan peralatan dalam satu kali proses produksi rata-rata adalah sebesar Rp 10.687 atau rata-rata sebesar $\mathrm{Rp} 320.613 /$ Bulan.

\section{Biaya Variabel (Variabel Cost)}

Biaya variabel adalah biaya yang digunakan dalam kegiatan usaha yang tergantung dari besar kecilnya produksi yang dihasilkan dan biasanya habis dalam satu kali proses produksi. Biaya variabel yang digunakan dalam usaha pembuatan bakso ayam di Kecamatan Belitang Kabupaten OKU Timur terdiri atas biaya pembelian bahan baku dan biaya tenaga kerja. Biaya bahan baku pembuatan bakso ayam digunakan untuk pembelian daging ayam, sagu, telur, bawang merah, bawang putih, lada bubuk, masako, MSG, garam, pengenyal, plastik, gas elpiji, air galon dan bensin. Biaya tenaga kerja dalam proses pembuatan bakso ayam digunakan untuk upah jasa penggilingan bakso, proses pembulatan bakso, perebusan, pengemasan dan pemasaran bakso ikan. Adapun besarnya biaya variabel usaha pembuatan bakso ayam yang terdiri dari biaya bahan baku dan biaya tenaga kerja dapat dilihat pada tabel 3 berikut:

Tabel 3. Biaya Variabel Usaha Pembuatan Bakso Ayam di Kecamatan Belitang Kabupaten OKU Timur, 2019.

\begin{tabular}{lr}
\hline No $\quad$ Komponen Biaya & Nilai (Rp/Proses) \\
\hline 1. Biaya Bahan Baku & $\mathbf{2 6 1 . 8 3 3}$ \\
a. Daging Aam & 128.333 \\
b. Sagu & 36.667 \\
c. Telur & 14.000 \\
d. Bawang Putih & 8.233 \\
e. Bawang Merah & 7.767 \\
f. Lada Bubuk & 9.333 \\
g. Masako & 7.333 \\
h. MSG & 2.667 \\
i. Garam & 3.667 \\
j. Pengenyal & 13.333 \\
k. Plastik & 15.000 \\
1. Gas Elpiji & 8.000 \\
m. Bensin & 7.500 \\
n. Air galon & 4.667
\end{tabular}

2. Biaya Tenaga Kerja

81.333

3. Biaya Variabel
Sumber : Olahan Data Primer, 2019.

Berdasarkan hasil pada tabel 3 diatas, dapat diketahui bahwa besarnya biaya pembelian bahan baku dalam satu kali proses produksi rata-rata adalah sebesar Rp 261.833 atau rata-rata sebesar $\mathrm{Rp}$ 7.855.000/Bulan. Besarnya biaya tenaga kerja dalam satu kali proses produksi rata-rata adalah sebesar Rp 81.333 atau sebesar Rp 2.440.000/Bulan. Besarnya biaya variabel usaha pembuatan bakso ayam di Kecamatan Belitang Kabupaten OKU Timur yang terdiri dari biaya bahan baku dan biaya tenaga kerja dalam satu kali proses produksi rata-rata adalah sebesar Rp 347.833 atau rata-rata sebesar $\mathrm{Rp}$ 10.435.000/Bulan.

\section{Biaya Total (Total Cost)}

Biaya total dalam usaha pembuatan bakso ayam terdiri dari biaya tetap ditambah dengan biaya variabel. Besarnya biaya total usaha pembuatan bakso ayam di Kecamatan Belitang Kabupaten OKU Timur disajikan pada tabel 4 berikut :

Tabel 4. Total Biaya Produksi Usaha Pembuatan Bakso Ayam di Kecamatan Belitang Kabupaten OKU Timur, 2019.

\begin{tabular}{|c|c|c|c|}
\hline No & Komponen Biaya & Nilai (Rp/Proses) & Nilai (Rp/Bulan) \\
\hline \multirow[t]{3}{*}{1.} & Biaya Tetap & 10.687 & 320.613 \\
\hline & a. Sewa Lahan & $\begin{array}{r}0.001 \\
6.019\end{array}$ & 180.556 \\
\hline & Penyusutan Peralatan & 4.669 & 140.058 \\
\hline \multirow[t]{3}{*}{2.} & Biaya Variabel & 347.833 & 10.435 .000 \\
\hline & Biaya Bahan Baku & 266.500 & 7.955 .000 \\
\hline & Biaya Tenaga Kerja & 81.333 & 2.440 .000 \\
\hline 3. & Total Biaya Produksi & 358.520 & 10.755 .613 \\
\hline
\end{tabular}

Sumber : Olahan Data Primer, 2019.

Berdasarkan hasil pada tabel 4, dapat diketahui bahwa biaya tetap usaha pembuatan bakso ayam yang terdiri dari biaya sewa lahan dan biaya penyusutan peralatan dalam satu kali proses produksi adalah sebesar Rp 10.687 atau rata-rata sebesar Rp 320.613/Bulan. Biaya variabel yang terdiri dari biaya bahan baku dan biaya tenaga kerja dalam satu kali proses produksi rata-rata adalah sebesar Rp 347.833 atau rata-rata sebesar Rp 10.435.000/Bulan, sehingga diperoleh total biaya produksi usaha pembuatan Bakso Ayam Kecamatan Belitang Kabupaten OKU Timur yang terdiri biaya tetap ditambah biaya variabel dalam satu kali proses produksi rata-rata adalah sebesar $\mathrm{Rp} 358.520$ atau rata-rata sebesar $\quad \mathrm{Rp} \mathrm{10.755.613/Bulan.}$

\section{B. Produksi, Harga, Penerimaan dan Pendapatan}

Hasil akhir atau produksi dalam usaha pembuatan bakso ayam adalah berupa bakso ayam. Produksi adalah jumlah bakso ayam yang dihasilkan selama satu kali proses produksi dan diukur dalam satuan kilogram. Satu kali proses proses membutuhkan waktu rata-rata selama satu hari. Rata-rata produksi bakso ayam yang dihasilkan dalam satu kali proses produksi adalah sebanyak $11 \mathrm{Kg}$ atau rata - rata sebanyak $330 \mathrm{Kg} /$ Bulan. Pada bulan-bulan tertentu terjadi kenaikan jumlah produksi, yaitu tahun 2019 terjadi pada bulan Februari, Mei, dan Juni. Hal disebabkan oleh faktor meningkatnya permintaan bakso akibat bulan puasa dan lebaran. Adapun harga 
jual rata-rata bakso ayam adalah sebesar Rp 40.000/Kg.

Penerimaan merupakan perkalian antara produksi bakso ayam yang dihasilkan dengan harga jual bakso ayam. Berdasarkan hasil analisis data diketahui bahwa produksi bakso ayam rata-rata sebanyak $11 \mathrm{Kg}$ per proses dan harga jual rata-rata bakso ayam sebesar Rp 40.000/Kg maka dihasilkan rata-rata penerimaan adalah sebesar $\mathrm{Rp}$ 440.000/Proses atau rata-rata penerimaan sebesar Rp 13.200.000/Bulan. Pendapatan usaha merupakan hasil dari penerimaan dikurangi dengan biaya produksi. Rata-rata total biaya produksi usaha pembuatan bakso ayam dalam satu kali proses adalah sebesar Rp 358.520 atau rata-rata sebesar Rp 10.755.613/Bulan. Rata-rata penerimaan usaha pembuatan bakso ayam adalah sebesar Rp 440.000/Proses atau rata-rata $\mathrm{Rp}$ 13.200.000/Bulan sehingga pendapatan usaha pembuatan bakso ayam di Kecamatan Belitang Kabupaten OKU Timur dalam satu kali proses produksi rata-rata adalah sebesar Rp 81.480 atau rata-rata sebesar Rp 2.444.387/Bulan. Adapun produksi, harga, penerimaan dan pendapatan usaha pembuatan bakso ayam di Kecamatan Belitang Kabupaten OKU Timur dapat dilihat pada tabel 5 berikut :

Tabel 5. Produksi, Harga, Penerimaan dan Pendapatan Usaha Pembuatan Bakso Ayam di Kecamatan Belitang Kabupaten OKU Timur, 2019.

\begin{tabular}{ccccc}
\hline No & Uraian & Satuan & Nilai/Proses & Nilai/Bulan \\
\hline 1. & Produksi & $\mathrm{Kg}$ & 11 & 330 \\
2. & Harga & $\mathrm{Rp} / \mathrm{Kg}$ & 40.000 & 40.000 \\
3. & Penerimaan & $\mathrm{Rp}$ & 440.000 & 13.200 .000 \\
& Biaya & $\mathrm{Rp}$ & 358.520 & 10.755 .613 \\
4. & Produksi & & & \\
& Pendapatan & $\mathrm{Rp}$ & 81.480 & 2.444 .387 \\
5. & R/C Rasio & & 1,23 & 1,23 \\
6. & & & & \\
\hline
\end{tabular}

Sumber : Olahan Data Primer, 2019.

Tingkat keuntungan suatu analisis usaha dapat dinyatakan melalui $\mathrm{R} / \mathrm{C}$ rasio (revenue per cost ratio). Analisis R/C rasio dapat digunakan untuk mengetahui rasio tingkat keuntungan suatu usaha yang dijalankan. Berdasarkan hasil perhitungan pada tabel 5 di atas maka diperoleh nilai $\mathrm{R} / \mathrm{C}$ rasio usaha pembuatan bakso ayam adalah sebesar 1,23. Nilai R/C rasio sebesar 1,23 artinya bahwa setiap satu rupiah biaya yang dikeluarkan untuk usaha pembuatan bakso ayam maka akan menghasilkan penerimaan sebesar Rp 1,23 atau dari setiap Rp 1 biaya yang dikeluarkan untuk usaha pembuatan bakso ayam maka akan diperoleh pendapatan sebesar Rp 0,23. Karena nilai R/C > 1, ini menunjukkan bahwa usaha pembuatan bakso ayam di Kecamatan Belitang Kabupaten OKU Timur menguntungkan secara finansial untuk dijalankan.

\section{Analisis Nilai Tambah Usaha Pembuatan Bakso Ayam}

Nilai tambah suatu produk adalah hasil dari nilai produk akhir dikurangi dengan biaya antara yang terdiri dari biaya bahan baku dan bahan penolong tanpa biaya tenaga kerja. Nilai tambah merupakan nilai yang ditambahkan kepada barang dan jasa yang dipakai oleh unit produksi dalam proses produksi sebagai biaya antara. Proses pengolahan daging ayam menjadi bakso ayam akan memberikan nilai tambah bagi daging ayam itu sendiri. Sedangkan untuk menghasilkan produk berupa bakso ayam tersebut diperlukan faktor-faktor produksi lain mulai dari tenaga kerja, peralatan produksi, bahan-bahan tambahan dan lain-lain

Tabel 6. Rata-rata Nilai Tambah Usaha Pembuatan Bakso Ayam di Kecamatan Belitang Kabupaten OKU Timur, 2019.

\begin{tabular}{clcc}
\hline No & \multicolumn{1}{c}{ Uraian } & Satuan & Nilai \\
\hline 1. & Kebutuhan Daging Ayam & Kg/Proses & 4 \\
2. & Produksi Bakso ayam & Kg/Proses & 11 \\
3. & Harga Jual Bakso ayam & Rp/Kg & 40.000 \\
4. & Nilai Akhir Bakso ayam & Rp/Proses & 440.000 \\
5. & Total Biaya Produksi & Rp/Proses & 358.520 \\
6. & Biaya Tenaga Kerja & Rp/Proses & 81.333 \\
7. & Biaya Antara (Intermediate & Rp/Proses & 277.187 \\
8. & Nilai Tambah & Rp/Proses & 162.813 \\
9. & Nilai Tambah (Kg) & Rp/Kg & 44.284 \\
\hline Sumber : Olahan Data Primer, 2019.
\end{tabular}

Nilai akhir bakso ayam atau penerimaan bakso ayam diperoleh dari produksi bakso ayam yaitu sebanyak $11 \mathrm{Kg} /$ Proses dikali dengan harga jual bakso ayam sebsar $\mathrm{Rp} \mathrm{40.000/Kg} \mathrm{sehingga} \mathrm{diperoleh} \mathrm{nilai}$ akhir bakso ayam adalah sebesar Rp 440.000/Proses. Dalam memproduksi bakso ayam pelaku usaha tidak menggunakan tenaga dari luar keluarga sehingga diperoleh nilai biaya tenaga kerja sebesar Rp 81.333. Biaya antara atau Intermediate Cost (IC) diperoleh dari total biaya produksi sebesar Rp 358.520/Proses yang dikurangi dengan biaya tenaga kerja (Rp 81.333/Proses) sehingga diperoleh nilai rata-rata biaya antara (IC) adalah sebesar Rp 277.187/Proses.

Nilai tambah diperoleh dari total penerimaan atau nilai akhir bakso ayam sebesar 440.000/Proses dikurangi dengan biaya antara yaitu sebesar $\mathrm{Rp}$ 277.187/Proses sehingga diperoleh nilai tambah usaha pembuatan bakso ayam adalah sebesar Rp 162.813/Proses produksi atau diperoleh nilai tambah per $\mathrm{Kg}$ pembuatan bakso ayam adalah sebesar Rp 44.284/Kg. Hal ini menunjukan bahwa setiap pembuatan bakso ayam dari $1 \mathrm{Kg}$ ayam akan memberikan nilai tambah sebesar $\mathrm{Rp}$ 44.284. Hal ini menunjukan bahwa usaha pembuatan bakso ayam di Kecamatan Belitang Kabupaten OKU Timur dapat memberikan nilai tambah secara finansial. Secara finansial keuntungan atau pendapatan yang diperoleh dari usaha pembuatan bakso ayam memang tidak 
terlalu besar karena usaha pembuatan bakso ayam ini masih dalam skala rumah tangga (skala mikro) namun usaha tersebut dapat menambah pendapatan keluarga. Para pelaku usaha pembuatan bakso ayam ini mengharapkan ada pembinaan dan bantuan dari pemerintah melalui instansi terkait sehingga usahana dapat lebih berkembang.

\section{Analisis Kelayakan Aspek Finansial}

Analisis kelayakan usaha agribinis adalah upaya untuk mengetahui tingkat kelayakan atau kepantasan untuk dikerjakan dari suatu usaha, dengan melihat beberapa parameter atau kriteria kelayakan tertentu. Studi kelayakan merupakan bahan pertimbangan dalam mengambil suatu keputusan, menerima atau menolak suatu usaha yang direncanakan. Perhitungan analisis finansial menggunakan acuan tingkat suku bunga deposito Bank Indonesia selama 1 tahun yaitu rata-rata sebesar $8 \%$. Dengan menggunakan suku bunga acuan tersebut akan digunakan untuk mencari nilai Compounding Factor

\section{Analisis NPV}

Net Present Value (NPV) atau nilai sekarang bersih adalah analisis manfaat finansial yang digunakan untuk mengukur layak tidaknya suatu usaha dilaksanakan dilihat dari nilai sekarang (present value). Kriteria kelayakan dari usaha ini adalah : proyek layak jika NPV lebih besar dari nol (positif) dan sebaliknya proyek tidak layak jika NPV nilainya lebih kecil dari nol (negatif).

Tabel 7. Analisis NPV Usaha Pembuatan Bakso Ayam di Kecamatan Belitang Kabupaten OKU Timur, Tahun 2017- 2019.

\begin{tabular}{|c|c|c|c|c|c|c|c|}
\hline & & 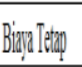 & B. Vyande & Bigyolodal & 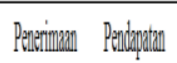 & CEPO & P. Valeery \\
\hline 2017 & $?$ & $40,09,333$ & $88,4626,60$ & $134,539,5893$ & 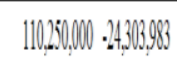 & 1.1660 & $.88348,1,166$ \\
\hline 2018 & 1 & 39,607 & 100,002,100 & $100,151,1,67$ & 131,40,000 301,288,233 & 1.000 & \\
\hline 2019 & 0 & 49,607 & $89,11,00$ & $90,190,607$ & $113,500000003,399,333$ & 1.000 & \\
\hline & & $49,99,607$ & $276,0,05,50$ & $365,969,417$ & 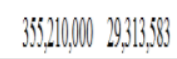 & .117 & \\
\hline
\end{tabular}

Sumber : Olahan Data Primer, 2019.

Hasil analisis pada tabel 7 diperoleh nilai investasi (biaya tetap) usaha pembuatan bakso ayam di Kecamatan Belitang selama 3 tahun adalah sebesar Rp 49.890.667. Biaya operasional (biaya variabel) selama 3 tahun adalah sebesar Rp 276.005.750 sehingga diperoleh biaya total produksi sebesar Rp 325.896.417. Total penerimaan usaha pembuatan bakso ayam selama 3 tahun adalah sebesar Rp 355.210.000 sehingga diperoleh total pendapatan usaha pembuatan bakso ayam selama 3 tahun adalah sebesar Rp. 29.313.583.

Berdasarkan perhitungan NPV selama 3 tahun usaha yaitu dari tahun 2017 sampai tahun 2019 dengan menggunakan Compounding Faktor dengan tingkat suku bunga acuan sebesar $8 \%$ maka diperoleh nilai NPV usaha pembuatan bakso ayam adalah sebesar Rp 27.692.459. Berdasarkan analisis diperoleh bahwa nilai NPV >0, Hal ini menunjukan bahwa usaha pembuatan bakso ayam di Kecamatan Belitang Kabupaten OKU Timur layak secara financial untuk diteruskan.

\section{Analisis IRR (Internal Rate of Return)}

IRR menunjukkan kemampuan suatu investasi atau usaha dalam menghasilkan return atau tingkat keuntungan yang bisa dipakai. Kriteria yang dipakai untuk menunjukkan bahwa suatu usaha layak dijalankan adalah jika nilai IRR lebih besar dari tingkat suku bunga yang berlaku pada saat usaha tersebut diusahakan (Gittinger, 2009). Jadi, jika IRR lebih tinggi dari tingkat bunga bank atau lebih tinggi dari Social Oportunity Cost of Capital (SOCC) maka usaha yang direncanakan layak secara finansial untuk dilaksanakan. Jika IRR lebih kecil dari SOCC maka usaha yang direncanakan tidak layak secara finansial.

Tabel 8. Analisis IRR Usaha Pembuatan Bakso Ayam di Kecamatan Belitang Kabupaten OKU Timur, Tahun 2017- 2019.

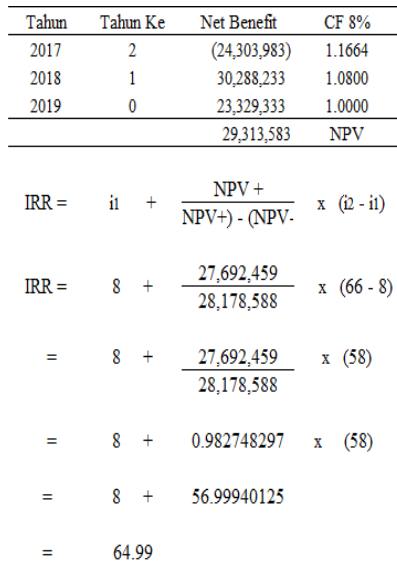

Sumber : Olahan Data Primer, 2019.

Berdasarkan perhitungan pada tabel 8 diperoleh nilai NPV positif (+) adalah sebesar Rp 27.692.459 dan nilai NPV negatif (-) terkecil dengan nilai interest (i $i_{2}$ sebesar 66\% adalah sebesar $\mathrm{Rp}$ (486.129). Berdasarkan hasil perhitungan dengan menggunakan Compounding Faktor, maka diperoleh nilai IRR usaha pembuatan bakso ayam adalah sebesar 64,99 \% yang berarti setiap rupiah yang diinvestasikan dalam pembuatan bakso ayam menghasilkan keuntungan sebesar 64,99 \% setelah didiskonto. Hal ini menunjukan bahwa usaha pembuatan bakso ayam di Kecamatan Belitang Kabupaten OKU Timur layak secara finansial untuk diteruskan.

\section{Analisis Net $\mathbf{B} / \mathbf{C}$}

Net Benefit Cost Ratio adalah penilaian yang dilakukan untuk melihat tingkat efisiensi penggunaan biaya berupa perbandingan jumlah nilai bersih sekarang yang positif dengan jumlah nilai bersih sekarang yang negatif, atau dengan kata lain Net B/C adalah perbandingan antara jumlah NPV positif dangan jumlah NPV negatif. Net B/C menunjukan nilai pendapatan bersih setelah dikenai bunga bank. Kriteria ini memberikan pedoman bahwa suatu proyek akan dipilih apabila nilai (Net $B / C>1)$, sebaliknya 
bila suatu proyek memberikan nilai (Net $B / C<1)$, maka proyek tidak diterima (diteruskan).

Tabel 9. Analisis Net B/C Usaha Pembuatan Bakso Ayam di Kecamatan Belitang Kabupaten OKU Timur, Tahun 2017- 2019.

\begin{tabular}{ccccc}
\hline Tahun & Tahun Ke & Net Benefit & CF 8\% & Present Value 8\% \\
\hline 2017 & 2 & $(24,303,983)$ & 1.1664 & $(28,348,166)$ \\
2018 & 1 & $30,288,233$ & 1.0800 & $32,711,292$ \\
2019 & 0 & $23,329,333$ & 1.0000 & $23,329,333$ \\
\hline & & Jumlah & $56,040,625$ \\
\hline
\end{tabular}

Net $B / C=\frac{\sum(N B) \overline{(+)}}{\sum(\mathrm{NB}) \overline{(-)}}$

$=\frac{56,040,625}{28,348,166.2}$

1.98

Sumber : Olahan Data Primer, 2019.

Nilai net $\mathrm{B} / \mathrm{C}$ diperoleh dengan menjumlahkan nilai Present Value Benefit (PVB) positif (+) kemudian hasilnya dibagi nilai PVB negatif (-). Berdasarkan hasil perhitungan pada tabel 9, diperoleh nilai PVB positif adalah sebesar Rp. 56.040.625. Nilai PVB negatif adalah sebesar Rp. 28.348.166 sehingga diperoleh nilai Net B/C adalah sebesar 1,98. Nilai net B/C 1,98 artinya bahwa setiap Rp 1 modal yang dikeluarkan untuk usaha pembuatan bakso ayam maka akan diperoleh keuntungan bersih setelah didiskonto (dikenai suku bunga bank) sebesar Rp 1,98. Nilai Net $B / C>1$ berarti usaha pembuatan bakso ayam di Kecamatan Belitang Kabupaten OKU Timur layak secara finansial untuk dikembangkan.

Berdasarkan perhitungan analisis NPV, IRR dan Net B/C di atas menunjukan bahwa usaha pembuatan bakso ayam di Kecamatan Belitang Kabupaten OKU Timur layak secara finansial.

Tabel 10. Analisis Kelayakan Finansial Usaha Pembuatan Bakso Ayam di Kecamatan Belitang Kabupaten OKU Timur, Tahun 2017- 2019 pada Tingkat Suku Bunga 8\% $(\mathrm{cf}=8 \%)$

\begin{tabular}{llcc}
\hline No & Uraian & Satuan & Nilai \\
\hline 1. & NPV & Rp & 27.692 .459 \\
2. & IRR & $\%$ & 64,99 \\
3. & Net B/C & & 1,98
\end{tabular}

Sumber : Olahan Data Primer, 2019

\section{KESIMPULAN DAN SARAN}

\section{A. Kesimpulan}

1. Total biaya produksi usaha pembuatan bakso ayam di Kecamatan Belitang Kabupaten OKU Timur dalam satu kali proses produksi rata-rata adalah sebesar $\mathrm{Rp} 358.520$, penerimaan adalah sebesar Rp 440.000, pendapatan yang diterima adalah sebesar Rp 81.480 .

2. Besarnya nilai tambah usaha pembuatan bakso ayam di Kecamatan Belitang
Kabupaten OKU Timur dalam satu kali proses adalah sebesar Rp 162.813 atau sebesar $45.562 / \mathrm{Kg}$. Hal ini menunjukan bahwa setiap pembuatan bakso ayam dari 1 $\mathrm{Kg}$ ayam maka akan memberikan nilai tambah sebesar Rp 44.284.

3. Usaha pembuatan bakso ayam di Kecamatan Belitang Kabupaten OKU Timur layak (feasible) secara finansial, hal ini dapat diketahui dari perhitungan nilai NPV yaitu sebesar Rp 27.692.459, nilai IRR adalah sebesar 64,99\% dan nilai Net B/C sebesar 1,98 .

\section{B. SARAN}

1. Hendaknya pelaku usaha pembuatan bakso ayam agar tetap memperhatikan dan menjaga kualitas bakso ayam yang dihasilkan dengan mempertahankan citarasa dan kebersihan tempat usahanya.

2. Hendaknya pelaku usaha pembuatan bakso ayam agar dapat meningkatkan kapasitas produksi bakso ayam yang dihasilkan sehingga dapat meningkatkan pendapatan.

3. Pemerintah melalui instansi terkait agar lebih membina industri skala mikro dengan memberikan bantuan modal usaha atau kredit mikro sehingga dapat lebih berkembang lagi.

\section{DAFTAR PUSTAKA}

Arsyad, L. 2003. Ekonomi Manajerial. Edisi Kelima. Balai Pustaka. Yogyakarta .

Diah dan Regina. 2007. Analisis Kadar Gizi dan Zat Aditif Dalam Bakso Sapi Dari Beberapa Konsumen. Fmipa UNY9 :116-23.

Faizul . 2009. Ekonomi Makro. Graha Ilmu. Yogyakarta.

Firdaus, M. 2008. Manajemen Agribisnis. Bumi Aksara. Jakarta.

Hermanto, F. 2010. Ilmu Usaha Tani. Penebar Swadaya. Jakarta.

Hermanianto dan Andayani 2002. Studi Prilaku Konsumen dan Identifikasi Parameter Bakso Sapi Berdasarkan Preferensi Konsumen di Wilayah DKI Jakarta, Retrieved From jurnal Teknologi Industri Pangan, vol X111, No 1 Hal 1-10.

Ibrahum, Y. 2009. Stady Kelayakan Bisnis. Rineka. Jakarta.

Joersan. 2003. Teori Ekonomi Mikro. Selemba Empat. Jakarta.

Kastasapoetra. 2006. Manajemen Pertanian Agribisnis. P.T Gramedia. Jakarta.

Mubyarto. 2006. Ekonomi Pertanian. Ghalia Indonesia. Jakarta.

Mubaryoto. 2001. Pengantar Ekonomi Pertanian. LP3ES. Jakarta.

Manullang. 2008. Pengantar Ekonomi Perusahaan. Ghalia Indonesia. Jakarta.

Mulyadi. 2007. Sistem Perencanaan dan Pengendalian Manajemen. Salemba Empat. 
Soekartawi. 2002. Analisis Usahatani. Universitas Indonesia. Jakarta.

----. 2005. Agroindustri Dalam Perspektif Sosial Ekonomi. Raja Grafindo Persada. Jakarta.

Sukirno. 2010. Makro Ekonomi, Teori Pengantar. Edisi ke Tiga. PT. Raja Grafindo Persada. Jakarta.

Saragih, B. 2001. Suara dari Bogor Membangun Sistem Agribisnis. Yayasan USES Bekerjasama dengan SUCOFINDO. Bogor.

Sjarkowi, dan Marwan, S. 2004. Manajemen Pembangunan Agribisnis. CV Baldad Grafiti Press. Palembang.

Yuyun. 2008. Bangkitnya Bisnis Kuliner Tradisional. Gramedia. Jakarta. 